\title{
Pre-Service Teachers' Knowledge of and Attitudes to Some Environmental Education Concepts Using Value Education Strategies
}

\author{
Joseph . O. Ogunbiyi* and Josiah O Ajiboye** \\ *Department of Sociological Studies, Tai Solarin University of Education, Ijebu-Ode, Nigeria \\ E-mail: ogunbiyiolukayode@yahoo.com \\ **Department of Primary Education, University of Botswana, PB00702, Gaborone, Botswana \\ E-mail: ajiboyejo@mopipi.ub.bw
}

KEYWORDS Environmental Valuing. Environmental Knowledge. Environmental Attitudes. Environmental Problems. Values Clarifications. Pre-Service Teachers. Nigeria

\begin{abstract}
The culture of environmental valuing has not been taken seriously in Nigeria at present. This has resulted into the deteriorating state of the environment. It is therefore important that strategies for effective environmental control be put in place. When preparing teachers for EE, innovative strategies should be explored because teachers normally teach the way they were taught. The study therefore investigated the effects of value analysis, value clarification and action learning on the environmental knowledge, attitudes and problem solving skills of pre-service teachers in some Nigeria Colleges of Education. The pre-test, post-test, control group, quasi-experiment design was used for the study. Two null hypotheses were generated and tested at.05 level of significance. Environment knowledge Test (EKT) and Environmental Attitudes Scale (EAS) were the instruments used for data collection. The data were analyzed using Analysis of covariance, multiple classification analysis and Duncan post-hoc test. The study found out that value education strategies were more effective in promoting subjects' cognitive and affective achievement in environmental education than conventional lecture method. Based on the findings, the study recommended that innovative instructional strategies like value analysis, value clarification and action learning should be adopted in Nigerian Colleges of Education to enhance effective teaching and learning of environmental education.
\end{abstract}

\section{INTRODUCTION}

In recent years, crises in the environment have become a national and international concern. People have realized the negative effects of environmental abuses on their health and welfare and they are starting to demand remedies to stop the increasing deterioration of our environment. However, the culture of environmental valuing has not been taken seriously in the developing countries of the world, most especially in Nigeria. This has resulted into the deteriorating state of the environment in these countries. There is an urgent need to adopt the culture of environmental valuing in Nigeria. In the last two decades there has been growing concern about the quality of the environment and how this relates to development. This concern itself has been precipitated by the clear evidence of a rapidly deteriorating environment, engendered by a combination of neglect, ignorance and harmful socio-cultural practices.

A number of seminars and conferences at local, national, regional and international level have been organized specifically to address this issue of environment and development. The most recent, and perhaps the most significant so far, was the United Nations Conference on Environment and
Development (UNCED), popularly known major document which emanated from this conference as Agenda 21, which summarizes the consensus which all the countries in attendance reached in terms of addressing the issues of the environment and sustainable development for all peoples of the world (United Nations 1992). A significant component of agenda 21 , especially from the point of view of developing countries of Africa, is the strong emphasis on the role of education in empowering people for sustainable development. The document states emphatically, as a major premise, the fact that people's level of knowledge, attitudes, values and practices are critical to the state of their environment, and how they utilize this environment for their own well-being (Muyanda-Mutebi and Yiga-Matowu 1993).

In effect, Agenda 21 serves further to confirm the critical position of environmental education (EE) in national and regional education systems. Following the Stockholm conference of 1972 and the Tbilisi conference of 1977, the main aims of environmental education have been identified as follows:

i. to provide opportunities to acquire the knowledge, value, attitudes, commitment and skills needed to protect and improve the environment; 
ii. to encourage people to examine and interpret the environment from a variety of perspectives - physical, geographical, biological, aesthetic, ethical and spiritual.

iii. to arouse people's awareness of and curiosity about the environment and encourage active participation in resolving environmental problems.

In Nigeria, as in many other developing countries, intense efforts are being made to integrate environmental education into the mainstream education system. The general view adopted is that, instead of introducing environmental education as another distinct school subject, it should rather assume an interdisciplinary approach "drawing on the specific contents of each discipline in making possible a holistic and balance perspective" (Nigeria Conservation Foundation 1990). For this to be done in any significant way, however, there is a need to collect baseline data on the prevailing environmental - related knowledge, attitudes, practices and beliefs of targeted cohorts of the population. This would, in effect, help to determine the "what" and "how" of a viable environmental education content.

\section{Literature Review on Action Learning}

The action learning approach is derived from a perspective that valuing includes a process of implementation as well as development. That is, it is important to move beyond thinking and feelings to acting. The approach is related to the efforts of some social studies educators to emphasize community - based rather than classroom based learning experiences. In some ways, it is the least developed of three strategies. However, a variety of recent programs have demonstrated the effectiveness of the techniques advocated by this approach (e.g. Cotton 2000; Gauld 2000; Solomon 2000).

The advocates of the action learning stress the need to provide specific opportunities for learners to act on their values. They see valuing primarily as a process of self-actualization in which individuals consider alternatives; choose freely from among those alternatives, prize, affirm and act on their choices. They place more emphasis on action taking inside and outside the classroom than is reflected in the moral development analysis and values clarification processes.

Values are not seen to have their sources neither in society nor in the individual but in the interaction between the person and the society, the individual, cannot be described outside of his or her context. The process of selfactualization, so important to the founders of the value clarification approach, is viewed as being tempered by social factors and group pressure in this way it is more related to Maslow's (1971) level of transcendence which he discussed towards the end of his career. A problem-solving / decision making model and related techniques that can serve as a sound beginning for this strategy is presented by Revan (1999):

- Input phase - a problem is perceived and an attempt is made to understand the situation of problem.

1) Identify the problem(s) and state it (them) clearly and concisely.

2) State the criteria that will be used to evaluate possible alternatives to the problems as well as the effectiveness of selected solutions; state any identified boundaries of acceptable alternatives, important value of feelings to be considered or results that should be avoided.

3) Gather information or facts relevant to solving the problems or making a decision.

- Processing Phase - alternatives are generated and evaluated and a solution is selected.

4) Develop alternatives or possible solutions

5) Evaluate the generated alternatives vis-à-vis the stated criteria

6) Develop a solution that will successfully solve the problem (diagnose possible with the solution and implications of these problems; consider the worst that can happen if the solution is implemented; evaluate in terms of overall " feelings" and "values").

- Output phase - includes planning for and implementing the solution.

7) Develop plan for implementation (sufficiently detailed to allow for successful implementation).

8) Establish methods and criteria for evaluation of implementation and success.

9) Implement the solution.

- Review Phase- the solution is evaluated and modifications are made, if necessary

10) Evaluating implementation of the solution (an on going process)

11) Evaluating the effectiveness of the solution

12) Modifying the solution in ways suggested by the evaluation process. Surprisingly, educators' use of the term "active 
learning" has relied more on intuitive understanding than a common definition. Consequently, many faculties assert that listening is inherently active and that students are therefore actively involved while listening to formal presentation in the classroom. Analysis of the research literature (Chickering and Gamson, 1987), however, suggested that students must do more than just listen: They must read, write, discuss or be engaged in solving problems. Most importantly to be actively involved students must engage in such higher order thinking tasks such as analysis and evaluation. Within this context, it is proposed that strategies promoting active learning be defined as instructional activities that engage students in doing things and thinking about what they are doing.

Use of these techniques in the classroom is vital because of their powerful impact upon students' learning. For example, several studies like that of Bloom (2001), Alex (2002), Buhaminda (2003), Collins (2004) and Allen (2005) have shown that students prefer strategies promoting active learning to traditional lectures methods. Other research studies evaluating students' achievement have demonstrated that many strategies promoting active learning are comparable to lectures in promoting the development of students' skills in thinking and writing. Further, some cognitive research has shown that a significant number of individuals have learning styles best reserved by pedagogical techniques other than lecturing. Therefore, a thoughtful and scholarly approach to skillful teaching requires that faculty become knowledgeable about the many ways strategies promoting active learning have been successfully used across the disciplines.

The modification of traditional lectures (Penner 1984) is one way to incorporate active learning in the classroom. Research has demonstrated, for example, that if a faculty member allows students to consolidate their notes by pausing three times for two minutes each during a lecture, students will learn significantly more information (Ruhl et al. 1987). Two other simple yet effective ways to involve students during a lecture are to insert brief demonstrations or short, un-graded writing exercises followed by class discussion. Certain alternatives to the lecture format further increase student level of engagement: (1) the feedback lecture, which consists of two mini lectures separated by a small - group session built around study guide and (2) the guided lecture, in which taking notes, followed by their writing for five minutes on what they remember and spending the remainder of the class period in small groups, clarifying and elaborating the materials.

Discussion in class is one of the most common strategies that promote active learning with good reason. If the objectives is to motivate students toward further learning to apply information in new settings or to develop students' thinking skills, then discussion is preferable to lecture. Research has suggested, however, that to achieve these goals, faculty must be knowledgeable of alternative techniques and strategies for questioning (Hyman 1980) and must create a supportive intellectual and emotional environment that encourage students to take risks (Lowman 1984).

Several additional strategies promoting active learning have been similarly shown to influence favourably students' attitudes and achievement. Visual - based instruction, for example can provide a helpful focal point for other interactive techniques in class writing across the disciplines is another productive way to involve students in doing things and thinking about the things they are doing. Some of the popular instructional strategies based on problem-solving model include the case study, debates, drama, role-playing and simulation and peer teaching. In short the published literature on alternatives to traditional classroom presentations provides a rich menu of different approaches faculty can readily add to their repertoire of instructional skills.

To address adequately why most faculty have not embraced recent calls for educational reform, it is necessary first to identify and understand common barriers to instructional change, including the powerful influence of educational tradition; faculty self-perceptions and self-definition of roles; the discomfort and anxiety that change creates; and the limited incentives for faculty to change. But certain specific obstacles are associated with the use of active learning including limited class time; a possible increase in preparation time; the potential difficulty of using active learning in large classes; and a lack of needed materials, equipments, or resources. Perhaps the single greatest barrier of all, however, is the fact that faculty members' efforts to employ active learning involve risks; the risks that students will not participate, use higher-order thinking, or learn sufficient content, that faculty 
members will feel a loss of control, lack necessary skills, or be criticized for teaching in unorthodox ways. Each obstacle or barrier, however, can be successfully overcome through careful and thoughtful planning.

The reform of instructional practice in higher education must begin with faculty members' efforts. An excellent first step is to select strategies promoting active learning that one can feel comfortable with. Such low risk strategies are typically of short duration, structured and planned focused on subject matter that is neither too abstract nor too controversial familiar to both the faculty member and the students. Faculty developers can help stimulate and support faculty members' efforts to change by highlighting the instructional importance of active learning in the newsletters and publications they distribute. Further, the use of active learning should become both the subject matter of faculty development workers and the instructional method used to provide follow up to and support for, faculty members' efforts to change.

Academic administrators can help these initiatives by recognizing and rewarding excellent teaching in general and the adoption of instructional innovations in particular. Comprehensive programs to demonstrate this type of administrative commitment (Cochran 1989) should address institutional employment policies and practices, the allocation of adequate resources for instructional development and the development of strategic administration plans.

Equally important is the need for more rigorous research to provide a scientific foundation to guide future practices in the classroom. Currently, most published articles on active learning have been descriptive accounts rather than empirical investigations, many are out of date, either chronologically or methodologically, and a large number of important conceptual issues have never been explored. New qualitative and quantitative research should examine strategies that enhance students' learning from presentations explore the impact of previously overlooked, yet educationally significant characteristics and be disseminated in journals widely read by faculty members.

In retrospect, it appears that previous classroom, initiatives and written materials about learning have all too often been isolated and fragmented. The resulting pedagogical efforts have therefore lacked coherence, and the goal of interactive classrooms has remained unfilled. However, through the coordinated efforts of individual faculty, faculty developers, academic administrators and educational researchers, higher education in the coming decades can make real the promise of active learning.

\section{The Study}

This study, which was largely experimental, was carried out to investigate the effects of value education strategies on pre-service teachers' environmental knowledge, attitudes and problemsolving skills in selected colleges of education in Nigeria.

\section{Hypotheses}

The following specific hypotheses were generated and tested @ p<.05 level of significance:

$\boldsymbol{H o}_{\mathbf{1}}$ : There is no significant main effect of treatment on pre-service teachers'

i. Knowledge of environmental concepts

ii. Attitudes to the environment

$\boldsymbol{H o}_{2}$ : There is no significant interaction effect of academic ability and gender on pre-service teachers'

i. Knowledge of environmental concepts

ii. Attitudes to the environment

\section{RESEARCH DESIGN}

A pre-test, post-test, control group, quasi experimental design was used for the study.

Four hundred part II social studies students were randomly selected from four colleges of education. The rationale for selecting part II students was because the environmental education concepts selected for study were offered at this level. The rationale for selecting the four colleges of education was because these colleges have large number of social studies students suitable for the study. Four major environmental issues discussed were: Environmental pollution, solid waste disposal, erosion, desertification and deforestation.

The instruments used which was developed by the researchers focused on five broad environmental issues identifies as having particular relevance to the Nigeria situation.

The following instruments were designed and used by the researchers: 


\section{Environmental Knowledge Test}

The instrument consists of two sections. Section one of the instrument seeks to obtain background information from the respondents. Section two consists of thirty multiple-choice objective test items. Each item has four option (A-D) from which respondents are to select the correct alternative. The main objective of this instrument was to test the pre-service teachers' environmental knowledge. This test was trial tested to ensure its reliability using Kuder Richardson formula $(\mathrm{Kr} 21)$. The reliability coefficient of the test was calculated as 0.79 . This shows that the instrument was reliable. The average item difficulty score was 0.46 . This indicated that the items of the instrument were neither too difficult nor too simple.

\section{Environmental Attitudes Scale (EAS)}

The instrument consists of two sections. Section one of the instrument seeks to obtain background information from the respondents. Section two of the instrument consists of thirty items on pre-service teachers' environmental attitudes. The attitudes scale used consists of a set of statement which student-teachers gave their responses based on four point Likert scale of: Strongly Agree (SA) 4, Agree (A) 3, Disagree (D) 2, Strongly Disagree (SD) 1 .

The main objective of this instrument was to measure the affective domain of the student teachers. Each of the respondents was required to tick the appropriate option as stated above for positively worded items and negatively worded items. The instrument was trial tested to ensure its reliability using Cronbach co-efficient alpha, which gives 0.80 while the standard items alpha calculated gives 0.83 . This shows that all the items in this instrument were reliable.

\section{Research Procedures}

The procedures are in phases as follows:

Phase 1: Training Sessions: There was a training programme for the research assistants. The training lasted for one week in each college. All social studies lecturers in the four colleges of education selected were involved in the training. It is important to stress, however, that those lecturers who scored $80 \%$ and above on the research's training rating scale were selected to participate in the study. Two lecturers were finally selected in each of the colleges.

Lecturers in experimental group one were trained on values analysis, lecturer in experimental group two were trained on value clarification, while Lecturers in experimental group three were trained on action learning and those in the control group were not exposed to value education strategies. This training programme lasted for four weeks. One week for each of the four groups in their various colleges. The packages designed for this training programme are: Values Analysis Teacher's Guide, Values Clarification Teachers' Guide, Action Learning Teachers' Guide and Conventional Method Teachers' Guide

At the end of the training programme in each college, demonstration lessons were conducted by the researcher to provide research assistants with a model.

Phase 2: The researchers with the cooperation of the Head of Social Studies Department in each of the colleges of education collected the part one result of the student-teachers. The researchers used the results to group the students into high and low academic ability group.

Phase 3: Pre-Test: Pre-service teachers' Environmental Knowledge Test (PTEKT), Environmental Problem-Solving Skills Test (EPSST) and Pre-service Teachers' Environmental Attitude Scale were administered as pre-test. The three instruments were administered before the commencement of the treatment to the students in all experimental and control groups.

Phase 4: Treatment: The research ran concu-rrently in all the selected colleges with each college taught using each of the strategy. Details of the procedure in each strategy are as follows: Values Analysis Strategy (VAS)

The steps are as follows:

- Orientation of the students to equip them on how to react in the class when the Value analysis strategy (VAS) is being used.

- Introduces the topic and the concept to be learnt to the students.

- Guide the students in identifying, analysis and explaining of a problem. Here the teacher assists in defining the terms to be used.

- Guide the students in stating hypothesis; examine facts, drawing inferences and developing tentative solutions.

- Get students to assemble evidence, arrange evidence, analyze and test hypothesis.

- Get students to identify alternative solution and find meaningful patterns of relationship. 
- Ask students to draw conclusion, apply the conclusion and test it against new evidence before generalizing the result.

- Ask students some questions based on how to analyze and solve environmental problems.

Values Clarification Strategy (VCS)

The steps involved were as follows:

- Orientation of the subjects on how to react in the class when the (VCS) is being used.

- Find out students prior knowledge on the topic through relevant questions.

- Allow the students to choose from alternatives.

- Give the students chance to choose freely.

- Let them affirm their choices.

- Provide opportunity for them to act upon their choices.

- Encourage them to act repeatedly over time.

- Allow them to use both rational and emotional awareness to examine their personal feeling, value and behaviour patterns.

- Evaluate the students by asking them relevant questions.

Action Learning Strategy (ALS)

The steps involved were as follows:

- Orientation of the subjects on how to relate and react in the class when the (ALS) is being used.

- Find out students prior knowledge on the topic through relevant questions.

- Allow them to put the theoretical knowledge already gained into action.

- Let the students identify a problem- this is the input phase.

- Let the students generate alternative and ask them to evaluate them this is the processing phase.

- The solution should be evaluated and modification should be made-this is the review phase.

- Evaluate the students by asking them relevant questions.

Phase 5: Post-Test: Pre-service teachers' Environmental Knowledge Test (PTEKT), Environmental Problem-Solving Skills Test (EPSST) and Pre-service Teachers' Environmental Attitude Scale were administered as post-test. The three instruments were administered before the commencement of the treatment to the students in all experimental and control groups.

\section{Data Analyses}

Analysis of Covariance (ANCOVA) was used to determine the main and interaction effects of the variables under study. Also the Multiple Correlation Analysis (MCA) was used to determine the magnitude of the performance of students in the various groups. Duncan post hoc test was also employed where significant main and interaction effects were obtained.

\section{RESULTS AND DISCUSSIONS}

The results were presented in the order in which the hypotheses were tested.

$\mathrm{Ho}_{\mathbf{I}}$ : There is no significant main effect of treatment on pre-service teachers' knowledge of environmental concepts.

The summary of findings regarding this hypothesis is presented in Table 1.

Table 1 shows that there is a significant main effect of treatment on pre-service teachers' knowledge of environmental concept $\left(\mathrm{F}_{(3,383)}=\right.$ $16.156 ; \mathrm{P}<.05$ ) > Based on this, H01 (i) is rejected. This shows that there is significant main effect of treatment on pre-service teachers' knowledge of environmental concepts. MCA (Table 2) explains how each of the treatment groups performed.

From this table, it could be observed that subjects in experimental group 2- Values clarification obtained the highest mean score (20.67), followed by the Experimental Group 3Action learning (20.52). Experimental group 1Values analysis came third with mean score of 19.02 while the control Group (Conventional strategy) had the lowest mean score of 16.28. To determine the actual source of the observed significant differences as indicated in the ANCOVA, a Duncan post-hoc analysis was carried out on the mean scores of the groups. The summary is presented in table 3 .

Table 3 indicates that whereas there is a significant difference in the mean scores of each of the three treatment groups and the control group, the difference between the mean score of the treatment groups were not significant.

$\boldsymbol{H o}_{2}$ : There is no significant main effect of treatment on pre-service teachers' attitudes to the environment.

In testing this hypothesis, data collected were analyzed using Analysis of Covariance (ANCOVA). The results are presented in table 4

Table 4 shows that there is a significant main effect of treatment on pre-service teachers' attitudes to the environment $\left(\mathrm{F}_{(3.383)}=3.250\right.$; $\mathrm{P}<.05)$. Based on this, Ho1 (ii) is rejected. This 
Table 1: Summary of $4 \times 2 \times 3$ ANCOVA of the Post-Test Achievement Scores of Subjects in Knowledge of Environmental Concepts According to Treatment, Academic Ability and Gender

\begin{tabular}{lccccc}
\hline Source of variation & Some of squares & Df & Mean square & F & Sig. of F \\
\hline Covariates & 103.018 & 1 & 103.018 & 5.754 & 0.017 \\
Main Effects (Combined) & 961.361 & 5 & 192.272 & 10.74 & 0 \\
Treatment & 867.688 & 3 & 289.229 & 16.156 & $.000 *$ \\
Academic Ability & 57.213 & 1 & 57.213 & 3.196 & 0.075 \\
Gender & 36.46 & 1 & 36.46 & 2.037 & 0.154 \\
2 Way Interactions & 264.124 & 7 & 37.732 & 2.108 & $.042 *$ \\
$\quad$ Treatment/Academic Ability & 99.838 & 3 & 33.279 & 1.859 & 0.136 \\
$\quad$ Treatment/ Gender & 36.29 & 3 & 12.097 & 0.676 & 0.567 \\
Academic Ability/ Gender & 117.489 & 1 & 117.489 & 6.563 & $.011 *$ \\
3-way Interaction & & & & \\
$\quad$ Treatment/ Academic & 85.987 & 3 & 28.662 & 1.601 & 0.189 \\
Ability/ Gender & 1414.49 & 16 & 88.406 & 4.938 & 0 \\
$\quad$ Explained & 6856.75 & 383 & 17.903 & & \\
$\quad$ Residual & 8271.24 & 399 & 20.73 & & \\
$\quad$ Total & & & & \\
\hline
\end{tabular}

*Significant at $\mathrm{P}<.05$

Table 2: Multiple Classification Analysis (MCA) of the Post-Test Achievement Scores of Subjects According to Treatment, Academic Ability and Gender

GRAND MEAN $=19.13$

\begin{tabular}{|c|c|c|c|c|c|}
\hline $\begin{array}{l}\text { Variable+ } \\
\text { Category } \\
\text { Treatment }\end{array}$ & $N$ & $\begin{array}{l}\text { Unad- } \\
\text { justed }\end{array}$ & Eta & $\begin{array}{c}\text { Adjusted } \\
r \text { Indepen- } \\
\text { dent }+ \\
\text { Covariate } \\
\text { Deviation }\end{array}$ & Beta \\
\hline \multicolumn{6}{|l|}{ Treatment } \\
\hline $\begin{array}{l}\text { 1. Values } \\
\text { analysis }\end{array}$ & 100 & 0.39 & 0.2 & -.10 & \\
\hline $\begin{array}{l}\text { 2. Value } \\
\text { clarificat }\end{array}$ & $\begin{array}{l}100 \\
\text { ion }\end{array}$ & 0.85 & 0.2 & 1.54 & 0.38 \\
\hline $\begin{array}{l}\text { 3. Action } \\
\text { learning }\end{array}$ & 100 & 0.36 & & 1.39 & 0.06 \\
\hline 4. Control & 100 & -1.6 & & & \\
\hline \multicolumn{6}{|l|}{ Gender } \\
\hline 1. Male & 124 & 0.32 & 0.04 & -2.84 & \\
\hline 2. Female & 276 & -1.4 & & 0.45 & \\
\hline \multicolumn{6}{|c|}{ Academic Ability } \\
\hline 1. High & 242 & 0.48 & 0.13 & -0.2 & 0.8 \\
\hline 2. Low & 158 & -0.75 & & & \\
\hline Multiple $\mathrm{R}^{2}$ & & & & 0.31 & 0.12 \\
\hline Multiple R & & & & -4.8 & 0.35 \\
\hline
\end{tabular}

Table 3: Summary of Duncan Post-hoc Analysis of Post-test Environmental Knowledge Scores of Subjects According to Treatment Groups.

\begin{tabular}{lccccc}
\hline Treatment & $X$ & $A C$ & $V A$ & $V C$ & Control \\
\hline Action learning & 20.52 & & & & \\
Values analysis & 19.02 & & $*$ & $*$ & \\
Values clarification & 16.28 & $*$ & $*$ & $*$ & \\
\hline *Pairs of groups that significantly differ & at & $p<.05$
\end{tabular}

indicates that treatment has a significant effect on the variations in subjects' attitude score. MCA (Table 5) explains how each of the treatment groups performed.

Table 5 shows that Experimental Group 3 Action learning obtained the highest mean score (87.43); followed by Experimental group 1 - values analysis with mean score of (80.30). Values clarification came next with a mean score of (79.86), while the control group,(Conventional strategy) had the lowest mean score of 78.07. However, to determine the actual source of the observed significant difference as indicated in the ANCOVA (Table 6).

Duncan post-hoc analysis was carried out on the groups' means and the summary is presented in table 6 above. Table 6 indicates that whereas there is significant difference in the mean scores of the three treatment groups and the control group, the difference among the treatment groups were not significant.

With regards to influence of academic ability on subjects' performance, results show that there is no significant interaction effect of academic ability and treatment on their performance. However, there was a significant interaction effect of academic ability and gender on pre-service teachers' knowledge of environmental concepts. The results presented in Table 1 revealed that there is significant interaction effect of academic ability and gender on pre-service teachers' knowledge of environmental concepts. ( $\mathrm{F}=$ $(3,383)=6.563 ; \mathrm{P}<.05)$. Results presented in MCA Table 2 explained how each ability group 
Table 4: Summary of $4 \times 2 \times 2$ ANCOVA of the Post-Test Attitudes Scores of Subjects on the Environmental Issues According to Treatment, Academic Ability and Gender

\begin{tabular}{lccccc}
\hline Source of variation & Some of squares & Df & Mean square & $F$ & Sig. of F \\
\hline Covariates & 18.196 & 1 & 18.196 & 0.039 & 0.844 \\
Main Effect (combined) & 5807.69 & 5 & 1161.54 & 2.471 & $.032 *$ \\
Treatment & 4582.09 & 3 & 1527.36 & 3.25 & $.022 *$ \\
Academic Ability/ & 1205.91 & 1 & 1205.91 & 2.566 & 0.11 \\
Gender & 19.686 & 1 & 19.686 & 0.042 & 0.838 \\
2-way interactions (Combined) & 3869.93 & 7 & 552.848 & 1.176 & 3.315 \\
Treatment/Academic Ability & 518.568 & 3 & 506.189 & 1.077 & 0.359 \\
Treatment/ Gender & 2166.1 & 3 & 722.033 & 1.536 & 0.205 \\
Academic Ability/ Gender & 912.202 & 1 & 912.202 & 1.941 & 0.164 \\
3-way interactions & 2054.93 & 3 & 684.978 & 1.457 & 0.226 \\
Treatment/Academic Ability/ & 11750.8 & 16 & 734.422 & 1.563 & 0.076 \\
$\quad$ Gender Explained & 180011 & 383 & 470.001 & & \\
Residual & 191761 & 399 & 480.605 & & \\
Total & & & &
\end{tabular}

Table 5: Multiple Classification Analysis (MCA) of the Post-Test Attitudes Scores According to Treatment

Grand Mean $=81-41$

\begin{tabular}{|c|c|c|c|c|c|}
\hline $\begin{array}{l}\text { Variable+ } \\
\text { Category } \\
\text { Treatment }\end{array}$ & $N$ & $\begin{array}{l}\text { Unad- } \\
\text { justed }\end{array}$ & $\begin{array}{rr}\text { Eta } & A \\
& \text { for } \\
& \\
& C \\
& D \\
\end{array}$ & $\begin{array}{l}\text { Ijusted } \\
\text { Indepen } \\
\text { dent }+ \\
\text { lovariate } \\
\text { leviation } \\
\end{array}$ & Beta \\
\hline \multicolumn{6}{|l|}{$\overline{\text { Treatment }}$} \\
\hline $\begin{array}{l}\text { 1. Values } \\
\text { analysis }\end{array}$ & 100 & -0.78 & & 1.11 & \\
\hline $\begin{array}{l}\text { 2. Values } \\
\text { clarifica }\end{array}$ & $\begin{array}{l}100 \\
\text { ion }\end{array}$ & -0.97 & \multirow[t]{2}{*}{0.154} & 1.55 & \multirow[t]{3}{*}{0.163} \\
\hline $\begin{array}{l}\text { 3. Action } \\
\text { learning }\end{array}$ & 100 & 5.47 & & 6.01 & \\
\hline 4. Control & 100 & -3.7 & & -3.34 & \\
\hline \multicolumn{6}{|l|}{ Gender } \\
\hline 1. Male & 124 & 0.13 & \multirow[t]{2}{*}{0.004} & 0.33 & \multirow[t]{2}{*}{0.01} \\
\hline 2. Female & 276 & -5.88 & & -0.14 & \\
\hline \multicolumn{6}{|c|}{ Academic Ability } \\
\hline 1. High & 242 & 1.12 & \multirow[t]{2}{*}{0.064} & 1.44 & \multirow[t]{2}{*}{0.82} \\
\hline 2. Low & 158 & -1.72 & & -2.21 & \\
\hline Multiple $\mathrm{R}^{2}$ & & & \multirow{2}{*}{\multicolumn{3}{|c|}{$\begin{array}{l}0.03 \\
174^{2}\end{array}$}} \\
\hline Multiple R & & & & & \\
\hline
\end{tabular}

performed. The achievement scores of high academic ability subjects were higher than their counterparts with low academic ability. It is interesting to discover that female students in all the groups with high academic ability performed better than their male counterparts with low academic ability. This implies that academic ability influenced subject knowledge of environmental concepts more than gender. With regards to interaction effect of academic ability and gender on subjects' attitudes however, the results presented in table 4 revealed that there is no
Table 6: Summary of Duncan Post Analysis of Post Test Achievement Score in Environmental Attitudes According to Treatment Groups

\begin{tabular}{lccccc}
\hline Treatment & $X$ & $A C$ & $V A$ & $V C$ & Control \\
\hline Action learning & 20.52 & & & & \\
Values analysis & 19.02 & & & & \\
Values clarification & 16.28 & $*$ & $*$ & $*$ & \\
\hline *Pairs of groups that differ significantly & 0 & $0<05$
\end{tabular}

*Pairs of groups that differ significantly @ p<.05

significant interaction effect of academic ability and gender on pre-service teachers' attitudes to the environment. $(\mathrm{F}=(3,383)=1.941) ; \mathrm{P}>.05)$.

\section{CONCLUSIONS}

Findings from this study have study shown that value education strategies have positively affected pre-service teachers' knowledge of environmental concepts and attitudes to the environment. Based on the findings, it was recommended that instructional strategies like value analysis, value clarification and action learning be adopted in pre-service teacher education programmes to facilitate teachers' improved knowledge and attitudes about environmental.

\section{REFERENCES}

Abraham M 1970. Values for Sustainable Environment. Berkeley, C.A: University of California Press,

Adara OA 1996. Strategies in environmental education in Nigeria by the year 2000. Environmental Education Research, 2(2): 237-246.

Adara OA 1997. Improving the quality and outreach of environmental education in Nigeria. In: A Book of Readings of the World Council for Curriculum and Instruction (WCCI). Region 2. Jos Publishers. 
Adaralegbe A 1972. Philosophy for Nigerian Education. Proceeding for the Nigeria National Curriculum, Ibadan: Heineman Educational Book.

Agholor RN 1993. Environmental Education in Nonformal Sector. Proceeding of the 1st National conference on environmental education: Lagos.

Ahove MA 1997. The Potency of Concept Mapping and Analogy as Innovative Strategies for Teaching Selected concepts in Environmental Education. Proceedings of Ajimogobia Memorial Conference $40^{\text {th }}$ Anniversary of STAN, $178-181$.

Ahove MA, Mabo AA 2000. Perception and attitude to environmental concepts in chemistry texts. A call for collaborative action research among female teachers. Journal of Science Teachers Association of Nigeria,

Ajewole GA 1991. Strategies for effective teaching of environmental education in schools. Environmental Education Workshops and Seminar Proceeding, 1: 107-116.

Ajiboye JO 1996. A Self-learning Programme, the Modified Lecture Method and Students' Cognitive and Affective Outcomes in Some Population Education Concepts. Unpublished Ph. D. Thesis, University of Ibadan, Ibadan.

Ajzen B, Madden OO 1986 Knowledge and attitude in relation to environmental education among college students. Journal of Environmental Education, 27(5): 9-21.

Akinbote OA 1999. Sex differences in the cognitive and affective outcomes in socials studies in primary school pupils. African Journal of Educational Research, 5(1): 34-38.

Akinpelu JA 1981. An Introduction to Philosophy of Education. London: Macmillan Publishers.

Albert A 2001. An ideal theory of values. Journal of Values Education, 15(2): 140-156.

Alexandra O 2004. Effects of value analysis and values clarification on students' affective and cognitive achievement in environmental education. Journal of Environmental Education, Series 1(2): 18-32.

Alfred OO 2004. Effects of values education strategies on students' knowledge and attitudes. American Journal of Environmental Education, 14(9): 2035.

Andrew BD 2004. Importance of values education strategies on teaching environmental education. International Journal of Environmental Education, 22, 23: $14-34$

Archies M 2001. Moving into the educational mainstream; Environmental Education. Info brief, 26. Alexandria, VA: ASCD. tt:/www.ascd.org/ readingroom/infobrief/issue $26 . \mathrm{html}$

Bark D 1996. Environmental values education strategies: implication for teaching social studies. Corner Stone Journal of Values Education, 2(2): 18-34.

Boham O 2004. A Guide to Teaching and Learning Values Education. Lewes: Falmer Press.

Bloom B 2000. The Need for Values Theory. Lewes: Falmer Press.

Bloom B 2002. Values and values education strategies. Journal of Environmental Values Education, 4(12): 22-32. Columbia University Teachers College.

Bond D 1999. An Analysis of Valuation Strategies in Social Science Education. Unpublished Ph. D dissertation. Berkeley, C. A: School of Education, University of California.

Bora B 2002. Values education strategies: implication for social studies teaching. Journal of Environmental Values Education, 9: 101-114.

Cottom A 1996. Action Learning Strategy. New York: Collier Books.

Coleman O 2004. Values education strategy: effects on environmental knowledge and problem-solving skills in high school environmental education concepts. Asia Pacific Journal of Environmental Education, 25: 36-52.

Dick B 1997. Action Learning and Action Research. New York: Free Press.

Fafunwa AB 1990. Environmental Education for all: A speech delivered by the Honourable Minister for Education at the opening ceremony of a workshop on environmental education for Secondary School Teachers organized by Nigerian Conservation Foundation at the University of Lagos 13-15 June.

Far BO 2000. Academic ability and attitudes as determinant of students' achievement in environmental education. International Journal of Environmental Education and Information, 23(7): 120-136.

Federal Environmental Protection Agency (FEPA) 1989. National Policy on the Environment. Lagos.

Federal Government of Nigeria 1988. Decree No. 58 Establishing the Federal Environmental Protection Agency (FEPA).

Fien J. 1995. Teaching for a sustainable world: the environmental development and education project for teacher education. Environmental Education Research, 1: 21-33.

Fien J; Corcoran PB 1996. A curriculum model for environmental values education. Journal of Environmental Education, 14(3): 23-26.

Freire P 1972. Pedagogy of the Oppressed. HarmondsWorth: Penguin Books Publishers.

Frown S 2002. Living values for young and adult. Conner Stone Journal of Values Education, 20(2): 1-5.

Frown SGJ 1993. Character First: The Hyde School Difference San Francisco: ICS Press.

Georgia Department of Education. 1997. Value education implementation guides Atlanta, G.A.: Office Instructional services, Georgia Department of Education. Retrieved: December 1997.

Graffits B 2004. Effects of values clarification and action learning on students' environmental problem-solving skills and attitudes. Journal of Environmental Education, 19(23): 102-115.

Harms B 1977. Values Education Strategies: A practical Approach in Teaching Environmental Education. Lewes: Falmer Press.

Saheeblem OO 2004. Effects of values education strategies on students' cognitive, affective and psychomotor domains. Journal of Values Education, 12(2): 102-118.

Stronghill JO 2001. Values Education Strategies: A Handbook of Practical Strategies for Teachers and Students. New York: Hart Publishing Inc.

Stronghill JO 2002. Values Education Coherence and Purpose. San Francisco: Jossey Bass Publishers.

Superaka D ; Hedstrom J 1996. Values Education. Sourcebook Boulder Co: Social Science Education Consortium. 